\title{
Influence of CD38/PD1 co-expression on T cell subsets in HIV-TB co-infection
}

\author{
Sharada Ramaseri Sunder', Surekha Rani Hanumanth², Anuradha Bandaru', Satya Sudheer Pydi', \\ Sumanlatha Gaddam³, Subbanna Jonnalagada', Vijaya Lakshmi Valluri ${ }^{1,3^{*}}$ \\ From First International Science Symposium on HIV and Infectious Diseases (HIV SCIENCE 2012) \\ Chennai, India. 20-22 January 2012
}

\section{Background}

Excessive immune activation as indicated by CD38 expression is a characteristic feature of HIV progression. There are growing evidences suggesting that immune inhibitory signals such as PD1 expression also play an important role in progression of the disease. However, the relationship between these positive $(\mathrm{CD} 38)$ and negative (PD1) immune signals on T cells in HIV-TB co-infection has not been studied in detail so far.

\section{Methods}

Expression levels of CD4, CD8, CD38 and PD1 were analyzed in peripheral blood collected from HIV, TB, HIV-TB and healthy controls using standardized protocol on flow cytometer.

\section{Results}

The percentage CD8+/CD38+ and CD8+/PD1+ cells was high in HIV-TB and HIV when compared with control and $\mathrm{TB}$, while there was no significant difference between HIV and HIV-TB. The CD38+/PD1+ coexpression was significantly high $(\mathrm{p}<0.01)$ on $\mathrm{CD} 8+$ cells in HIV-TB when compared with HIV, control and TB groups, inferring that $\mathrm{CD} 38 / \mathrm{PD} 1$ phenotype distinguishes CD8 T-cell responses between HIV and HIV-TB co-infection.

\section{Conclusion}

High CD38+/PD1+ co-expression on CD8 cells probably causing a variation in CD8 cell responses could perhaps be a risk factor for development of tuberculosis in HIV-

\footnotetext{
* Correspondence: vijayavalluri@gmail.com

'LEPRA India - Blue Peter Public Health \& Research Centre, Cherlapally, Hyderabad, India

Full list of author information is available at the end of the article
}

positive individuals. The use of $\mathrm{CD} 8 / \mathrm{CD} 38 / \mathrm{PD} 1$ markers for HIV-TB needs contemplation.

\section{Author details}

'LEPRA India - Blue Peter Public Health \& Research Centre, Cherlapally, Hyderabad, India. ${ }^{2}$ Department of Genetics, Osmania University, Hyderabad, India. ${ }^{3}$ Bhagawan Mahavir Medical Research Centre, Hyderabad, India.

Published: 4 May 2012

doi:10.1186/1471-2334-12-S1-04

Cite this article as: Sunder et al:: Influence of CD38/PD1 co-expression on T cell subsets in HIV-TB co-infection. BMC Infectious Diseases 201212 (Suppl 1):04.
Submit your next manuscript to BioMed Central and take full advantage of:

- Convenient online submission

- Thorough peer review

- No space constraints or color figure charges

- Immediate publication on acceptance

- Inclusion in PubMed, CAS, Scopus and Google Scholar

- Research which is freely available for redistribution
C Biomed Central

\section{Biomed Central}

